\title{
ANT-LIKE SPIDERS OF THE GENUS MYRMARACHNE FROM THE PHILIPPINES
}

\section{BY NATHAN BANKS}

In the collection of Arachnida of the Philippine Islands in the Museum of Comparative Zoölogy are a number of specimens of the interesting ant-like genus Myrmarachne. Peckham described four species and the types are here, Karsch described one, and Chamberlin one species. The large species, M. maxillosus Koch, known from various parts of the Malay region, also occurs in the collection.

In this paper I shall treat only of the males, believing that we know too little as yet to place the females properly; in several cases, however, there are females with males to which they evidently belong. I have, therefore, not treated of $M$. edentulus which Peckham based on a female; quite possibly it is the female of $M$. bellicosus. The specific characters are best illustrated in the jaws, their shape and armature. The male palpi are so nearly alike in the several species that it appears they are less useful than in most spiders; the case is similar to that of Tetragnatha.

The following synoptic table will distinguish the forms so far known; doubtless there will be fully as many more to be found in the islands. Only one of the species is from Mindanao, most of them from Luzon. Except M. maxillosus none of the species agree with the species known from Ceylon, Malacca, Java, or Borneo.

1. Two teeth on outer upper edge of each jaw, jaws not constricted, fang without tooth, lower outer edge of fang-groove with a row of small teeth.......bidentata No teeth on outer upper edge of jaw

2. Inner upper edge of jaw with a prominent tooth before tip, and a large blunt tooth-like process at tip; jaws not constricted at base, abdomen not constricted, large dark species ......................maxillosus No tooth on upper inner edge of jaw before tip.... 3 
3. The jaws (seen from side) more or less plainly constricted on basal part and swollen above on apical part

The jaws (seen from side) not constricted on basal part, nor swollen on apical part, but even along the top

4. Abdomen very plainly constricted before middle; fang evenly curved, color yellowish throughout assimilis

Abdomen not plainly constricted above, fang sinuous

5. On lower outer edge of fang-groove a row of distinct teeth to near base, fang with blunt tooth near middle, jaws not much swollen toward tip ............opaca On lower outer edge of fang-groove only a few small teeth, not noticeable except near tip, fang without tooth

6. Jaws only a little swollen toward tip, fang but slightly sinuous; no tooth missing on lower inner edge toward tip

Jaws greatly swollen toward tip, fang plainly sinuous.

7. Color mostly dark bellicosus Color wholly pale yellowish dubius

8. Jaws more suddenly swollen on basal side, no prominent teeth on outer fang-grove, head more globose than usual tagalica

Jaws more gradually swollen on basal side, three prominent teeth near tip on outer fang-groove

megregori

9. Abdomen not constricted above, but very slender, cephalothorax very long, but slightly cut back of eyes, no tooth on fang, color iridescent above ....iridescens Abdomen constricted above, and with two shields, plainly separated. 
10. Fang with one (or two) teeth.......................... 11

Fang without tooth.......................................... 12

11. Fang with one long, and one very short or indistinct tooth; teeth on lower inner edge large, cephalothorax only slighted indented back of eyes..............chapmani

Fang with one short tooth; inner teeth on lower side small; cephalothorax deeply indented back of eyes piercei

12. Fang plainly sinuous; cephalothorax moderately indented, inner row of teeth even (not one missing), outer edge of fang-groove with row of distinct teeth seriatis

Fang evenly curved, no row of distinct teeth along outer edge of fang-groove.

13. On lower inner edge one tooth skipped, fang not constricted near tip, nor wrinkled, cephalothorax only slightly cut behind eyes, larger species bakeri

On lower inner edge no tooth skipped, all at subequal distances apart, fang wrinkled beneath and constricted before tip, cephalothorax more deeply cut back of eyes, smaller species nigella

\section{Myrmarachne bidentata sp. nov.}

Fig. 4

Cephalothorax dark red-brown, jaws red-brown, dorsal shield of abdomen dark red-brown, rest of abdomen brown; legs yellow-brown, tarsi 3 and 4 pale and coxæ 1 very pale. Cephalothorax but little indented back of eyes, only about the height of third eyes; eyes of second row as near third as to A. S. E. and higher up. Jaws heavy, shorter than the cephalothorax, seen from side convex above and below, sides transversely wrinkled from above rather broadest on apical third, outer edge with two prominent teeth, the apical one usually more blunt than the basal, the edge between sometime slightly concave, lower inner edge with a rather large apical tooth and about three before 
it, outer edge of fang-groove with a faint carina and several teeth, two near tip longer and more visible from side; fang slightly sinuous, without tooth. Palpi about as long as jaws, the tibia a little shorter than tarsus. Legs of moderate length; femur swollen at base more than others, tibia 1 with six pairs of long spines. Sternum narrow, anterior coxæ nearly touching, second coxæ also swollen within. Abdomen not constricted, with one large dorsal shield, truncate before tip, and with little if any indication of a basal division.

Body.-Length 6-7 mm.

From Mt. Makeling (Baker), Malinao, Tayabas (Baker), and Sarai, Paete, Laguna (McGregor).

\section{Myrmarachne maxillosus Koch}

Several specimens from Los Banos (Baker), Malinao, Tayabas (Baker). In one specimen the anterior tibia is short and with but four pairs of spines, others have the front tibia longer (though variable) and with more spines, but the characters of the jaws are the same in all.

Myrmarachne assimilis sp. nov.

Figs. 7, 13.

Pale yellowish throughout, jaws rather darker, fang dark red-brown, except pale tip. Cephalothorax very deeply cut behind eyes, much more so than usual, thoracic part scarcely rising behind cut; eyes of second row near to and a little above the anterior laterals. Jaws longer than the cephalothorax, much constricted on basal half, so that narrowest part (seen from side of above) is about half of the widest part, a faint outer carina, and an inner one on apical part, transverse wrinkles rather faint except on inner sides; on inner lower edge five teeth at subequal distances apart on apical half, a few small ones on basal part, outer edge of fang-groove with ten or more teeth, two near tip rather larger than the others which are very small; fang gently evenly curved, not at all sinuous. Palpi with tibia a little longer than tarsus. Legs very slender, front femora but 
little enlarged at base, tibia 1 with five outer and four inner spines. Sternum not very narrow, about as broad between coxæ 1 as between coxæ 2. Abdomen elongate, much constricted at basal third, with two separated shields, and showing some trace of dark marks.

Body.-Length $8 \mathrm{~mm}$.

From Mt. Makeling (Baker) also females probably belonging thereto, and a female from Calayan Island, (McGregor).

It is related to $M$. plataleoides Peck. from Ceylon, but the swollen part of the jaw is longer, and the tibia of palpus though elongate is not as much so as in $M$. plataleoides.

\section{Myrmarachne opaca Karsch}

Fig. 12.

Cephalothorax dark red-brown to black, the mandibles also; legs yellow brown to dark brown, often not marked; abdomen dark, nearly black. Cephalothorax quite deeply cut back of eyes, the thoracic part rising somewhat behind before sloping off to tip; eyes of second row plainly a little nearer to A. S. E. than to third row. Jaws fully as long or longer than the cephalothorax, constricted on basal half, but not as much so as in tagalica or megregori, about as much as in $M$. bellicosus, from above about one-half wider in widest place than at base, each edge with a carina, that on the inner side of apical part especially strong, on sides and above transversely wrinkled; lower inner edge with six or more teeth, those on apical part fairly large, but hardly at equal distances apart, lower outer edge of fang-groove marked with a long row of good-sized teeth, plainly visible from side all along to near the base; fang sinuous, and near middle with the beginning of a tooth. Palpi nearly as long as the jaws; the tibia about equal to tarsus; legs long and slender, the front tibia very long and with five pairs of spines; sternum moderately slender, plainly wider at coxa 2 than at coxa 1; abdomen rather short with one large shield above which on the anterior sides shows an indentation each side.

Body.-Length 6.5-7.5 mm. 
From Manila, Los Banos (Baker) ; Culasi, Panay (McGregor) ; and Philippine Islands (J. W. Chapman). Karsch described it briefly from Samar; in 1912 I examined his type. This species is related to $M$. turriformis Badcock, but the numerous teeth on outer edge of fang-groove separates it, the sternum is also narrower than the Malayan species. $M$. robustus Peck from Burmah is very close to $M$. turriformis, and perhaps the same, but tibia of palpus a little longer.

The $M$. tayabasanus Chamb. (1925) appears to be this species; the type is not here, and the description gives nothing to show it distinct from $M$. opaca; the marks on legs vary.

\section{Myrmarachne bellicosus Peck}

Besides the type we have specimens from Serai, Paete, Laguna, (McGregor), and several marked only Luzon. The second femora usually shows a black line more or less plainly.

\section{Myrmarachne dubius Peck}

I have seen no more than the type, and doubt if it is distinct from bellicosus, the femur 2 shows a trace of the dark line. One of the bellicosus is paler than others but none approach dubius in the practically wholly yellow color. I fail to find anything different in the jaws; both forms have four pairs of spines under tibia 1.

\section{Myrmarachne tagalica sp. nov.}

$$
\text { Figs. 1, } 10 .
$$

Cephalothorax reddish brown, almost black on top of head, jaws dull yellowish brown, legs yellowish brown, femora rather darker, abdomen nearly black above. Cephalothorax deeply cut behind eyes, and the side furrows also deep, behind cut rising slightly before sloping, cephalic part more globose than usual, the sides (seen from above) convex and hind corners well rounded. Jaws longer than cephalothorax, basal part much constricted, apical part 
greatly swollen, and the swelling starts rather suddenly, each upper edge with a carina, lower inner edge with four teeth in apical part and some small ones on basal part, outer edge of fang-groove marked by a row of small teeth, those near tip scarcely larger and not noticeable from side; fang sinuous, no tooth. Palpi short, tibia hardly as long as tarsus. Sternum not very narrow, at coxæ 1 fully one-half as wide as at coxæ 2 . Legs long and slender, tibia 1 fully twothirds as long as jaw, with four pairs of spines, and an extra one near tip. Abdomen short, not constricted, rounded above, the two shields practically united.

Body.-Length $4.5 \mathrm{~mm}$.

From Butuan, Mindanao (Baker).

Myrmarachne megregori sp. nov.

Figs. 9, 14.

Cephalothorax red brown, clothed with appressed white hair, eyes on black spots, jaws dark red brown, legs pale yellowish brown, front pair rather darker, palpus mostly pale, abdomen black above, paler beneath. Cephalothorax deeply cut behind eyes, and the side furrows also deep, thoracic part sloping behind; eyes of second row a little nearer to A. S. E. than to third row. Jaws much longer than cephalothorax, very large, basal part constricted, apical part much swollen, but the slope rather gradual, from above not twice as broad as at base, lower inner edge with about five teeth, outer edge of fang-groove marked by a row of teeth of which several near the tip are larger and noticeable from side; fang strongly sinuous, no tooth. Palpi much shorter than jaws, tibia 1 not two-thirds as long as jaw, with four pairs of spines. Sternum narrow, not onehalf as wide at coxæ 1 as at coxæ 2. Abdomen rather short, but little longer than the swollen part of jaw, evenly convex above, not constricted, but with two distinctly separated shields.

Body.-Length $3.2 \mathrm{~mm}$.

From Sarai, Paete, Laguna (McGregor). 
Myrmarachne chapmani sp. nov.

Figs. 6, 11.

Cephalothorax and jaws yellow-brown, black in front and around third eyes, legs yellowish; abdomen pale on basal half, beyond shining black, except extreme tip pale, anterior metatarsi slightly dark. Cephalothorax not deeply cut behind eyes, but side grooves are deep, and above the eye-region appears trilobed behind; eyes of second row about as near third row as to A. S. E. Jaws about as long as cephalothorax, straight, not constricted on basal part, from above the sides are nearly parallel, but outer somewhat convex, each edge with a carina; lower inner row of about seven large teeth, nearly evenly spaced, except near tip; outer edge of fang-groove not indicated and without teeth; fang long, scarcely sinuous, but with a very large tooth near basal third and the beginning of another near apical third. Palpi short, the tibia shorter than usual, no longer than broad. Legs short; femora, especially of leg 1 , swollen at base, tibia 1 with four pairs of spines. Sternum much narrowed between coxæ 1 , but moderately broad at coxæ 2. Abdomen elongate, constricted above, with two separate shields.

Body.-Length $4 \mathrm{~mm}$.

From Philippine Islands (J. W. Chapman), with ants.

Myrmarachne piercei sp. nov.

Fig. 2.

Cephalothorax with head black, thoracic part yellowish, base of abdomen pale, beyond dark, jaws red-brown, legs yellowish brown, metatarsi 1 dark, leg 2 pale, with a dark stripe in front of femur; leg 3 mostly brownish; leg 4 with coxæ, trochanters, and most of patellæ very pale, rest brown. Cephalothorax deeply cut back of the eyes, the thoracic part somewhat elevated behind cut; eyes of second row almost as near third row as to A. S. E. Jaws long, straight, hardly as long as the cephalothorax, not constricted above on basal part, upper edge with carina, outer side slightly convex, lower inner edge with only two or three small teeth toward tip, outer edge of fang-groove marked by a carina with a few small teeth scattered along 
to near base; fang slightly sinuous with a distinct tooth near basal third and beyond that wrinkled within. Palpi much shorter than jaws, the tibia little longer than broad. Sternum quite narrow, but about as much widened between coxæ 1 and 2 as behind coxæ 2. Legs moderately short, tibia 1 with four pairs of spines, one beneath on patella 1 . Abdomen rather long, plainly constricted above and on sides, and with two separate shields.

Body.-Length $6.5 \mathrm{~mm}$.

From Victorias and Manapla, Occ. Negros (Pierce).

A female similar to male except short jaws may be the same species.

Myrmarachne seriatis sp. nov.

Fig. 5.

Cephalothorax nearly black, clothed with fine appressed white hair; jaws red-brown; legs mostly yellow-brown, femora often dark, front femur, tibia and metatarsus mostly dark brown; abdomen black, a pale band across between shields. Cephalothorax cut quite deeply back of eyes, but posterior face of head sloping; eyes of second row a little nearer to A. S. E. than to third eyes; jaws fully as long as the cephalothorax, heavy, very thick near base (seen from side), not constricted on basal part, from above outer edge convex, broadest a little beyond middle, each upper edge with a carina, above transversely wrinkled, lower inner edge with about four rather small teeth on apical part, besides the larger and sharp apical tooth, basal part with many small teeth, outer edge of fang-groove marked by a long row of teeth, plainly visible from side; fang sinuous, without tooth, the inner edge before middle somewhat wrinkled. Palpi short, tibia moderately short. Legs not very long, leg 1 short, tibia with five pairs of spines below. Sternum moderately slender, about as wide at coxæ 1 as at coxæ 2. Abdomen moderately short, but with two distinct dorsal shields, and slightly constricted between them.

Body.-Length 4.5-5.5 mm.

From Culasi, Panay (McGregor). 
Myrmarachne bakeri sp. nov.

Fig. 8.

Cephalothorax brownish yellow, eyes on black band, jaws reddish brown, legs mostly dull yellowish, femora more brown, especially front ones, metatarsi 1 dark and a broad dark band on tibia 1. Abdomen dark, nearly black above, except tip, a pale band across between the shields. Cephalothorax only slightly cut behind eyes and then sloping off behind; eyes of second row about as near to the third row as to the A. S. E. Jaws longer than the cephalothorax, not constricted on basal part, the outer edge has a carina above and is plainly convex, a large tooth on inner edge near tip, one a little behind it, then a space equal to width of jaw before the next tooth followed by two more, and several very small, scattered teeth, not noticeable from sides; fang long, slender only slightly curved except at tip. Palpi much shorter than jaws, tibia about as long as tarsus. Legs fairly long and slender, tibia 1 with six pairs of spines beneath, one under the patella 1 . Sternum not very slender, almost as wide at front coxæ as at coxæ 2. Abdomen rather short, broadest toward tip, only slightly constricted above and on the sides at basal third, but with two distinctly separated shields.

Body.-Length 5-6 mm.

From Mt. Makeling (Baker).

Myrmarachne iridescens sp. nov.

Fig. 3.

Cephalothorax iridescent bronzy black; jaws red-brown; legs pale, femur 1 and metatarsus 1 and outer half of tibia dark, hind tibia and metatarsus lineate with dark; abdomen black, above iridescent. Cephalothorax very long, cut only a trifle back of eyes, the thoracic part sloping gradually, and much longer than head; second eyes about half way between third and A. S. E.; jaws only about two-thirds as long as cephalothorax, not constricted at base, from above the outer side is convex, the broadest a little before middle, each edge with carina, surface transversely wrinkled above, 
the inner edge produced in a sharp tooth, the lower inner edge with about five teeth, outer edge of fang-groove not marked by distinct teeth, fang but little curved. Palpi short, tibia shorter than tarsus. Legs slender, but rather short, femur 1 thick at base, tibia 1 with five pairs of spines below, patella with one spine. Sternum moderately narrow, a little narrower at coxæ 1 than at coxæ 2. Abdomen very long and slender, but not constricted above nor or on sides, and with one long shield above.

Body.-Length $4.5 \mathrm{~mm}$.

From Los Banos, Luzon, Phil. Islds. (Baker). The female with the males is similar in color and structure, except in having short mandibles.

\section{Myrmarachne nigella Simon}

Described by Peckham as S. niger, changed to nigella by Simon because Salticus niger was preoccupied. Besides the Peckham types we have it from Manila (Feb. 1917) and Dupax, Nueva Vizcaya, Luzon.

\section{Explanation of Plate 11.}

Fig. 1. Myrmarachne tagalica, jaw above.

Fig. 2. Myrmarachne piercei, side.

Fig. 3. Myrmarachne iridescens, side.

Fig. 4. Myrmarachne bidentata, jaw above.

Fig. 5. Myrmarachne seriatis, side.

Fig. 6. Myrmarachne chapmani, jaw above.

Fig. 7. Myrmarachne assimilis, side.

Fig. 8. Myrmarachne bakeri, jaw above.

Fig. 9. Myrmarachne mcgregori, side.

Fig. 10. Myrmarachne tagalica, side.

Fig. 11. Myrmarachne chapmani, side.

Fig. 12. Myrmarachne opaca, jaw above.

Fig. 13. Myrmarachne assimilis, jaw above.

Fig. 14. Myrmarachne mcgregori, jaw above and teeth near apex below.

Fig. 15. Myrmarachne opaca, side. 


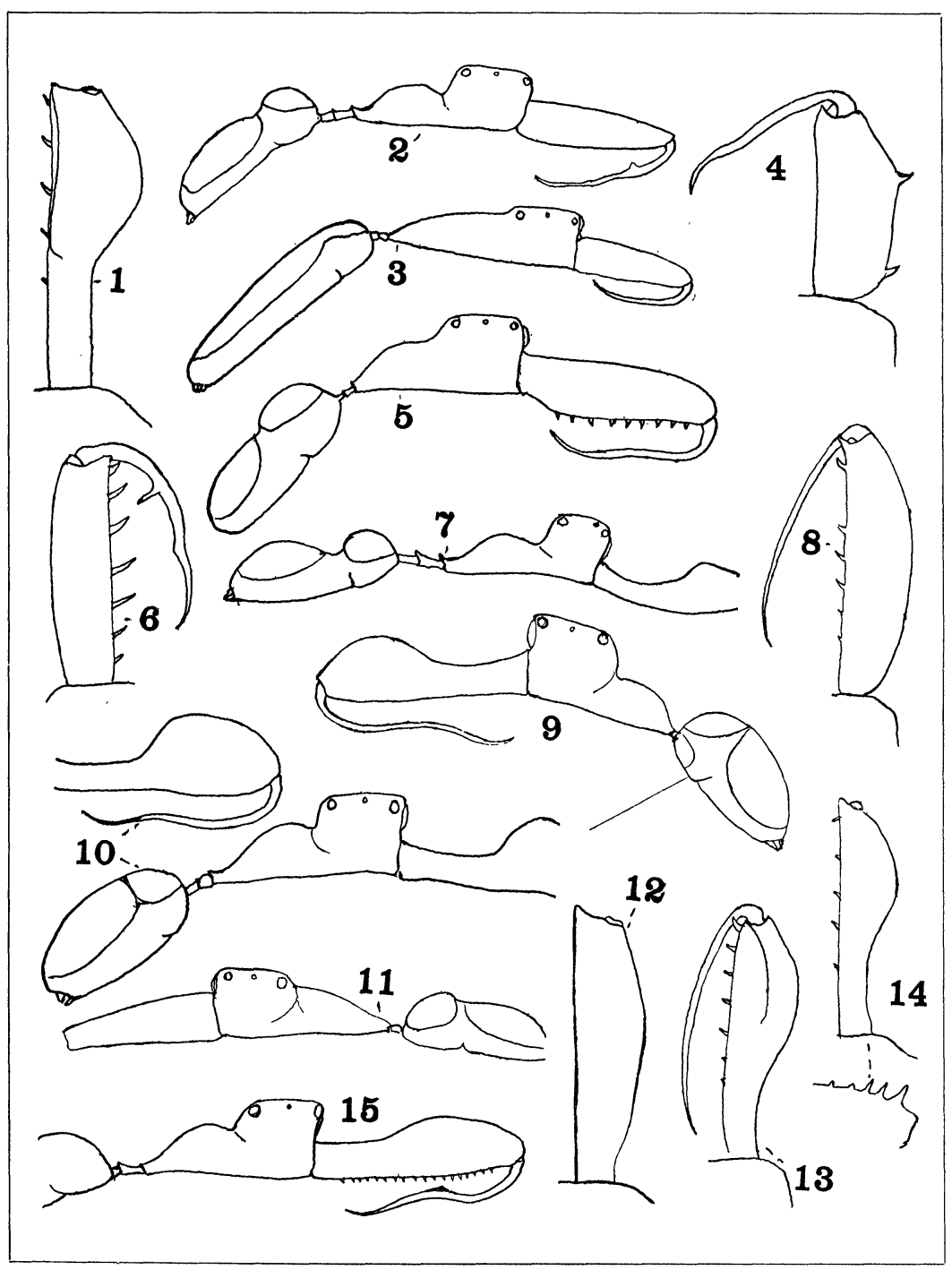

Plate 11.

Banks, Myrmarachne. 

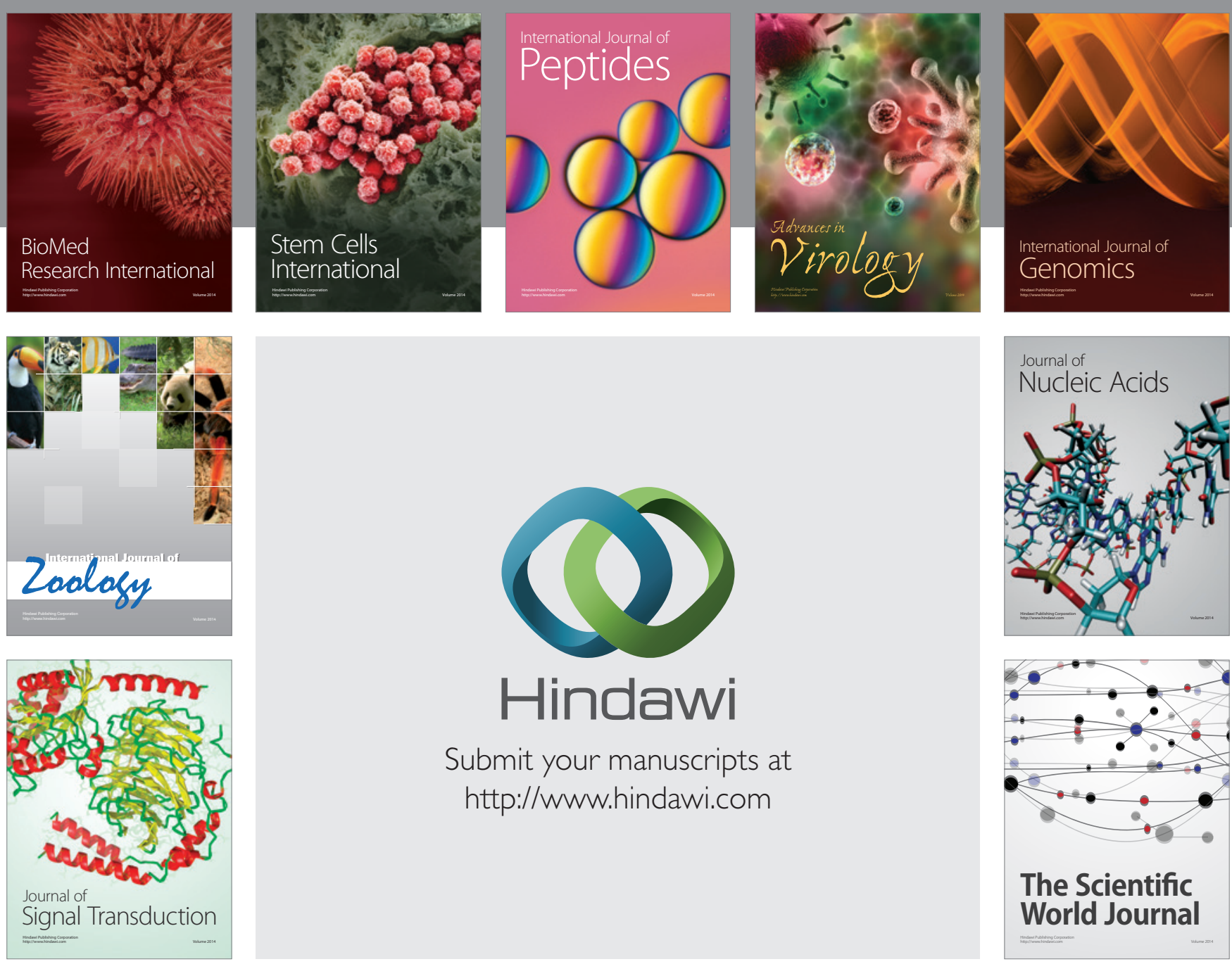

Submit your manuscripts at

http://www.hindawi.com
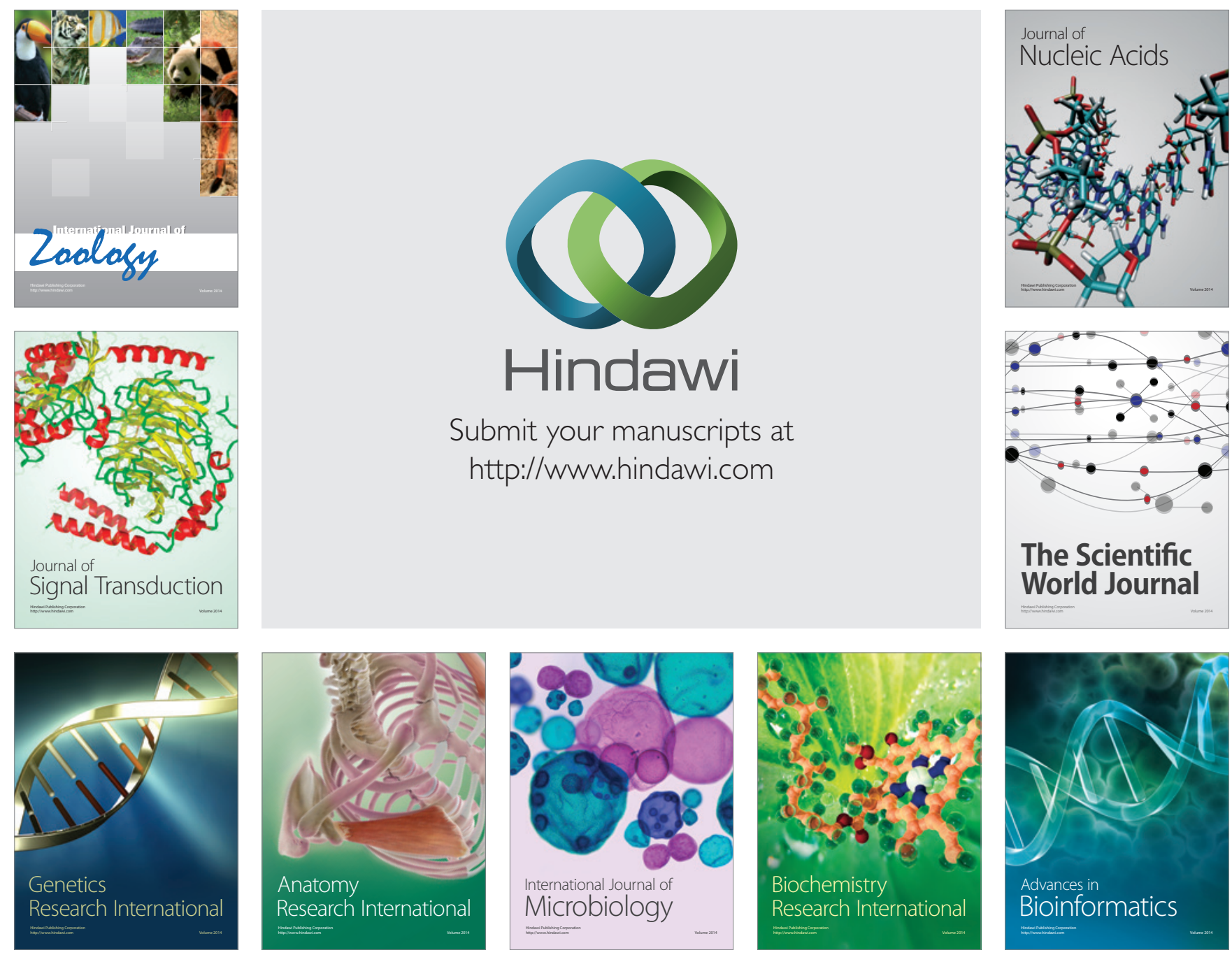

The Scientific World Journal
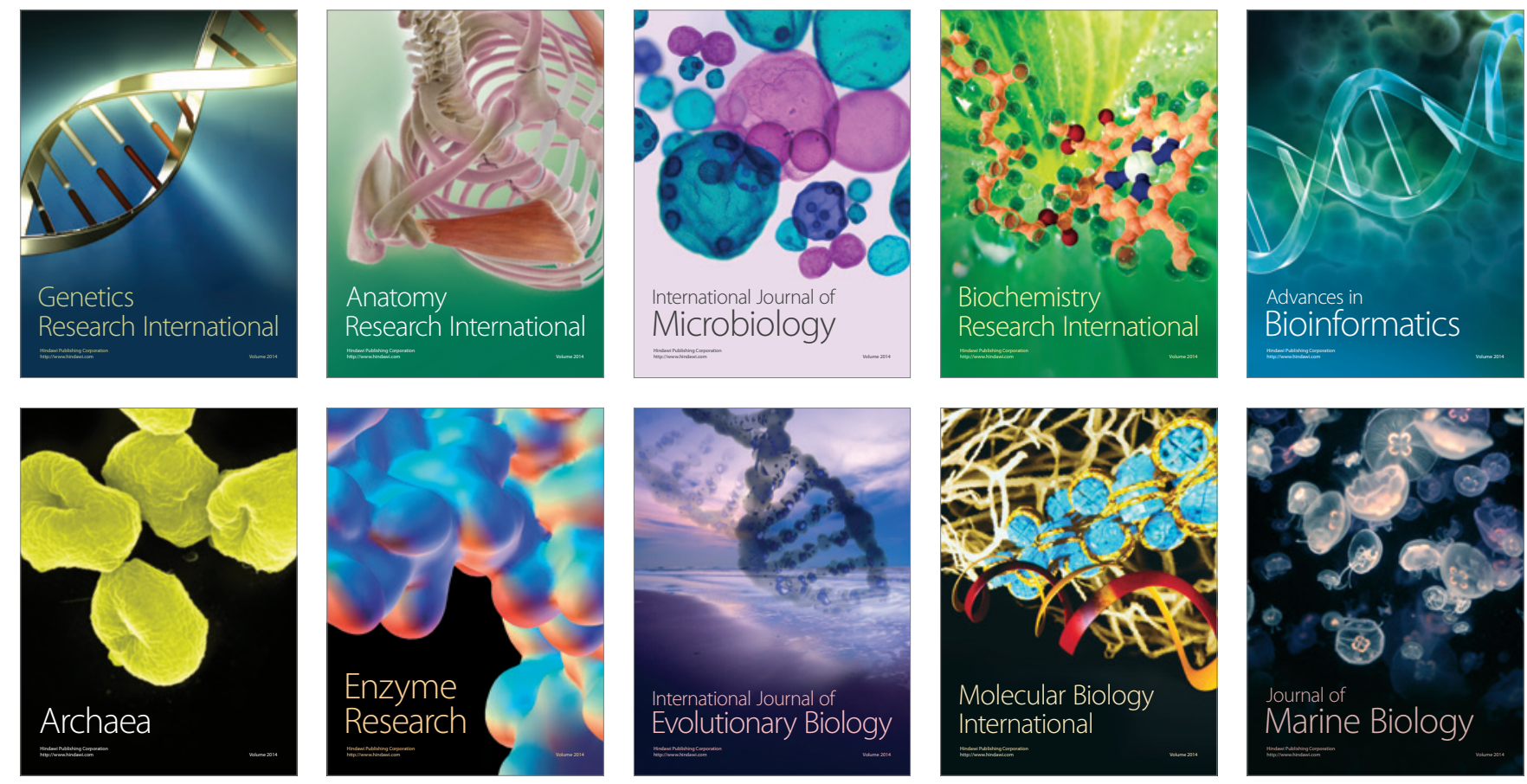